Марет ПАНК, О. КНРРЕТ, Надежда ПАБЕРНТ, А. ААВНКСААР

\title{
ВЛИЯНИЕ ОРГАНИЧЕСКИХ РАСТВОРИТЕЛЕЙ НА АКТИВНОСТЬ БАКТЕРИАЛЬНЫХ МЕТАЛЛОПРОТЕИНАЗ
}

Одной из возможностей увеличения выхода продукта в ферментативном синтезе пептидов под действием протеолитических ферментов является добавление в реакционную смесь органических растворителей с целью сдвига равновесия реакции в сторону образования пептидной связи. Так, показано, что константа равновесия в синтезе карбобензокси-L-триптофанил-глицинамида из N-карбобензокси-L-триптофана и глицинамида с помощью химотрипсина была в $85 \%$-ном по объему растворе 1,4-бутандиола в 80 раз больще, чем в водной среде ['].

Поскольку в последнее время в качестве катализаторов в пептидном синтезе стали применять бактериальные металлопротеиназы, в частности термолизин $\left[{ }^{2-6}\right]$, представляет интерес оценить возможности использования смешивающихся с водой органических растворителей для увеличения константы равновесия образования пептидной связи в присутствии ферментов. Систематические данные о влиянин органических растворителей на стабильность и активность бактериальных металлопротеиназ в литературе, однако, отсутствуют. Известно лишь, что небольшие концентрации диметилсульфоксида ингибируют гидролиз 3-(2-фурил) акрилоил-глицил-L-лейцинамида термолизином [7] и ряд других растворителей ингибируют как казеннолитическую, так и пептидазную активность этого фермента [8].

Так как в активном центре термолизинподобных протеиназ имеется гидрофобная полость для связывания боковой цепи аминокислотного остатка в положении $P_{1}^{\prime}$ (классификация по $\left.\left[{ }^{9}\right]\right)$ субстрата $\left[{ }^{10,11}\right]$, то можно думать, что в этой полости могут связываться липофнльнье молекулы органических растворителей, в результате чего при гидролизе будет наблюдаться эффект конкурентного ингибирования активности фермента. Тогда в координатах $k_{\mathrm{II}} \mathrm{H}_{2} \mathrm{O} / k_{\mathrm{II}}$ орг от концентрации органического растворителя должна наблюдаться линейная зависимость согласно уравнению

$$
k_{\mathrm{IIH}_{2} \mathrm{O}} / k_{\mathrm{IIopr}}=1+[I] / K_{I},
$$

где $k_{\mathrm{II} \text { орг и }} k_{\mathrm{II} \mathrm{H}_{2} \mathrm{O}}-$ бимолекулярные константы скорости ферментативного гидролиза субстрата в присутствии органического растворителя с концентрацией $[I]$ и в водной среде соответственно, $K_{I}-$ константа диссоциации фермент-ингибиторного комплекса $\left[{ }^{12}\right]$.

Для проверки этого предположения в настоящей работе исследовалось влияние диоксана, N,N-диметилформамида, 1,4-бутандиола, диметилсульфоксида и трет-бутанола на активность двух бактериальных металлопротеиназ - термолизина из Bacillus thermoproteolyticus и протеиназы из Bacillus brevis 7882. Отдельными опытами была проверена стабильность этих ферментов в присутствии высоких концентраций указанных растворителей в воде. 


\section{Экспериментальная часть}

Использовали термолизин фирмы «Calbiochem-Behring» (США); металлопротеиназа Bacillus brevis 7882 была выделена в нашей лаборатории $\left[{ }^{13}\right]$. Синтез субстратов, 3-(2-фурил) акрилоил-глицил-Lлейцинамида (ФАГЛА) и 3-(2-фурил) акрилонл-глицил-L-валинамида (ФАГВА), описан в [14]. Диоксан сушили над $\mathrm{Al}_{2} \mathrm{O}_{3}, \mathrm{KOH}$ и перегоняли над натрием, т. кип. $101^{\circ} \mathrm{C}, n_{D}^{20}=1,4224$. Диметилсульфоксид (ДМСО) сушили над молекулярными ситами и перегоняли в вакууме над $\mathrm{KOH}$, т. кип. $66^{\circ}$ при 8 мм рт. ст., $n_{D}^{20}=1,4770.1,4$-Бутандиол перегоняли в вакууме, т. кип. $120^{\circ}$ при 10 мм рт. ст., $n_{D}^{20}=1,4453$. трет-Бутанол очищали фракционной перегонкой, т. кип. $82-83^{\circ}, n_{D}^{20}=$ $=1,3879$. N,N-Диметилформамид (ДМФА) очищали согласно методике $\left[{ }^{15}\right]$, т. кип. $152^{\circ}, n_{D}^{20}=1,4303$.

Начальную скорость гидролиза субстратов измеряли на спектрофотометре «Beckman UV 5260» (США) по уменьшению оптической плотности реакционной смеси при 322 нм, $\mathrm{pH} 7,2$ и $25^{\circ}\left[{ }^{16}\right]$.

Для исследования стабильности термолизина и металлопротеиназы Bacillus brevis 7882 в присутствии 80 об. \% органических растворителей раствор фермента в $0,02 \mathrm{M}$ буфере трис-кислый малеат- $\mathrm{NaOH}$, $\mathrm{pH} 8,8,5 \mathrm{mM} \mathrm{CaCl}_{2}$ или в $1 \mathrm{M}$ буфере трис- $\mathrm{HCl}, \mathrm{pH} 8,8,10 \mathrm{mM} \mathrm{CaCl}_{2}$ добавляли в органический растворитель и полученную смесь инкубировали при $25^{\circ}$. Через различные промежутки времени из смеси отбирали пробы в кювету спектрофотометра (разбавление смеси в 100 раз) и определяли активность ферментов по скорости гидролиза ФАГЛА при рН 7,2 .

При исследовании влияния концентрации органического растворителя на гидролиз субстратов металлопротеиназами рассчитанное на определенный объем количество органического растворителя добавляли в буфер $0,2 \mathrm{M}$ трис-кислый малеат- $\mathrm{NaOH}, \mathrm{pH}$ приводили к 7,2 при помощи $1 \mathrm{H}$. $\mathrm{NaOH}$ и доводили объем до заданного значения буфером 0,17 м трис-кислый малеат-NaOH. В реакционную смесь брали по 0,8 мл такого раствора, добавляли по 0,2 мл раствора субстрата в буфере $0,17 \mathrm{M}$ трис-кислый малеат-NaOH, pH 7,2, содержащем 5 мM $\mathrm{CaCl}_{2}$, и определяли активность ферментов.

\section{Результаты и обсуждение}

Изученные бактериальные металлопротеиназы были стабильны в $80 \%$-ных по объему растворах 1,4-бутандиола и диоксана при $\mathrm{pH} 9$ в течение нескольких дней. Стабильность ферментов в ДМФА сильно зависит от $\mathrm{pH}$ раствора: металлопротеиназы стабильны в $80 \%$-ном растворе ДМФА при $\mathrm{pH} \mathrm{11,} \mathrm{но} \mathrm{при} \mathrm{переходе} \mathrm{к} \mathrm{pH} 9$ уже за час инактивируются более чем наполовину. Такая же зависимость наблюдается и в случае ДМСО, но его инактивирующие свойства при любых значениях рН значительно выше: в $80 \%$-ных растворах ДМСО даже прн высоких значениях $\mathrm{pH}$ активность металлопротеиназ уменьшается в 10 раз уже за час.

Результаты исследования влияния концентрации ДМСО, ДМФА, 1,4-бутандиола, диоксана и трет-бутанола на бимолекулярные константы скорости гидролиза ФАГЛА термолизином и протеиназой Bacillus bievis 7882 (табл. 1 и 2) свидетельствуют о том, что с повышением концентрации органических растворителей бимолекулярные константы скорости гидролиза исследованных субстратов значительно умень- 
Гидролиз 3-(2-фурил)акрилоил-глицил- $\mathrm{L}-{ }_{-1}$ ейцинамида термолизином в присутствии органических растворителей *

\begin{tabular}{|c|c|c|c|c|c|c|c|}
\hline $\begin{array}{l}\text { Раство- } \\
\text { ритель }\end{array}$ & $\begin{array}{c}\text { Концеңт- } \\
\text { рация, } \\
\text { об. \% }\end{array}$ & $\begin{array}{l}k_{\mathrm{II} \mathrm{opr}} \\
\cdot 10^{-3} \\
\mathrm{M}^{-1} \mathrm{c}^{-1}\end{array}$ & $\begin{array}{c}k_{\mathrm{II} \mathrm{H}} \mathrm{H}_{2} \mathrm{O} / \\
k_{\mathrm{II} \text { opr }}\end{array}$ & $\begin{array}{l}\text { Раство- } \\
\text { рителіь }\end{array}$ & $\begin{array}{c}\text { Концент- } \\
\text { рация, } \\
\text { об. \%. }\end{array}$ & $\begin{array}{c}k_{\mathrm{II} \mathrm{opr}} \\
\cdot 10^{-3} \\
\mathrm{M}^{-1} \mathrm{c}^{-1}\end{array}$ & $\begin{array}{c}k_{\mathrm{II} \mathrm{H}} \mathrm{O} / \\
k_{\mathrm{II}} \mathrm{opr}\end{array}$ \\
\hline \multirow[t]{2}{*}{ Диоксан } & \multirow{2}{*}{$\begin{array}{r}0,5 \\
1,0 \\
1,4 \\
1,9 \\
2,4 \\
3,2 \\
4,9 \\
10,0 \\
20,0 \\
29,1 \\
30,0\end{array}$} & \multirow{2}{*}{$\begin{array}{c}11,5 \\
8,2 \\
8,0 \\
5,8 \\
5,5 \\
4,8 \\
2,9 \\
1,0 \\
0,17 \\
0,05 \\
0,04 \\
\end{array}$} & \multirow{2}{*}{$\begin{array}{c}1,23 \\
1,73 \\
1,78 \\
2,45 \\
2,58 \\
2,96 \\
4,90 \\
14,2 \\
83,5 \\
284 \\
355 \\
\end{array}$} & $\begin{array}{l}\text { N,N-Диме- } \\
\text { тилформ- } \\
\text { амид }\end{array}$ & $\begin{array}{c}1,0 \\
1,4 \\
1,9 \\
2,35 \\
9,2 \\
18,6\end{array}$ & $\begin{array}{c}11,0 \\
10,0 \\
8,9 \\
7,8 \\
1,95 \\
0,6\end{array}$ & $\begin{array}{c}1,29 \\
1,42 \\
1,60 \\
1,82 \\
7,28 \\
23,7 .\end{array}$ \\
\hline & & & & \multirow[t]{2}{*}{$\begin{array}{l}\text { Диметил- } \\
\text { сульфоксид }\end{array}$} & \multirow{2}{*}{$\begin{array}{r}1,0 \\
2,0 \\
3,0 \\
5,0 \\
7,0 \\
10,0 \\
20,0 \\
30,0 \\
40,0 \\
50,0 \\
\end{array}$} & \multirow{2}{*}{$\begin{array}{r}13,0 \\
12,1 \\
10,4 \\
9,2 \\
7,8 \\
6,5 \\
3,8 \\
2,4 \\
1,2 \\
0,3 \\
\end{array}$} & \multirow{2}{*}{$\begin{array}{r}1,09 \\
1,17 \\
1,37 \\
1,54 \\
1,82 \\
2,18 \\
3,74 \\
5,92 \\
11,8 \\
47,3 \\
\end{array}$} \\
\hline \multirow[t]{2}{*}{ Диоксан ** } & \multirow[t]{2}{*}{$\begin{array}{c}0,9- \\
1,75 \\
2,2 \\
10,0 \\
20,4 \\
29,1\end{array}$} & \multirow[t]{2}{*}{$\begin{array}{l}0,69 \\
0,50 \\
0,46 \\
0,17 \\
0,02 \\
0,01\end{array}$} & \multirow[t]{2}{*}{$\begin{array}{c}1,59 \\
2,20 \\
2,39 \\
6,47 \\
55 \\
110\end{array}$} & & & & \\
\hline & & & & \multirow{2}{*}{$\begin{array}{l}\text { трет- } \\
\text { Бутанол }\end{array}$} & \multirow[b]{2}{*}{$\begin{array}{c}1,05 \\
1,6 \\
2,1 \\
2,4 \\
3,0 \\
5,0 \\
10,0 \\
20,0 \\
22,0 \\
30,0\end{array}$} & \multirow[b]{2}{*}{$\begin{array}{r}11,8 \\
10,8 \\
10,0 \\
9,6 \\
6,9 \\
4,4 \\
2,9 \\
0,9 \\
0,5 \\
0,3\end{array}$} & \multirow[b]{2}{*}{$\begin{array}{c}1,20 \\
1,31 \\
1,42 \\
1,48 \\
2,06 \\
3,23 \\
4,90 \\
15,8 \\
28,4 \\
47,3\end{array}$} \\
\hline $\begin{array}{l}\text { 1,4-Бутан- } \\
\text { диол }\end{array}$ & $\begin{array}{r}0,9 \\
1,4 \\
1,9 \\
2,4 \\
3,0 \\
5,0 \\
10,0 \\
19,8 . \\
30,0 \\
50,0\end{array}$ & $\begin{array}{c}12,9 \\
11,9 \\
10,8 \\
10,4 \\
10,2 \\
7,3 \\
3,5 \\
1,4 \\
0,65 \\
0,08\end{array}$ & $\begin{array}{c}1,10 \\
1,19 \\
1,31 \\
1,37 \\
1,39 \\
1,95 \\
4,06 \\
10,7 \\
21,8 \\
178\end{array}$ & & & & \\
\hline
\end{tabular}

* Условия ре акци и: буфер 0,17 М трис-кислый малеат-NaOH, $\mathrm{pH} 7,2,1$ м. $\mathrm{CaCl}_{2} ; 25^{\circ} \mathrm{C} ;[E]_{0}=0,02-6 \mathrm{мкM} ;[S]_{0}=0,1 \mathrm{мM}$.

** Субстрат 3-(2-фурил) акрилонл-глицил-L-валинамид.

Таблица 2

Гидролиз 3-(2-фурил) акрилоил-глицил-L-лейцинамида металлопротеиназой Bacillus brevis 7882 в присутствии органических растворителей *

\begin{tabular}{|c|c|c|c|}
\hline Растворитель & $\begin{array}{l}\text { Концент- } \\
\text { рация, } \\
\text { об. \% }\end{array}$ & $\begin{array}{c}k_{\mathrm{II}} \text { opr } \cdot 10^{-3} \\
\mathrm{M}^{-1} \mathrm{c}^{-1}\end{array}$ & $\begin{array}{c}k_{\mathrm{II} \mathrm{H} \mathrm{H}_{2} \mathrm{O}} / \\
k_{\mathrm{II} \text { opr }}\end{array}$ \\
\hline \multirow[t]{3}{*}{ Диоксан } & 5,0 & 1,04 & 4,46 \\
\hline & 9,8 & 0,49 & 9,47 \\
\hline & 15,7 & 0,38 & 12,2 \\
\hline \multirow[t]{3}{*}{ 1,4-Бутандиол } & 4,9 & 2,64 & 1,76 \\
\hline & 9,8 & 1,12 & 4,14 \\
\hline & 15,4 & 0,79 & 5,87 \\
\hline \multirow{4}{*}{$\begin{array}{l}\mathrm{N}, \mathrm{N} \text {-диметил- } \\
\text { формамид }\end{array}$} & 2,4 & 2,75 & 1,69 \\
\hline & 4,8 & 1,87 & 2,48 \\
\hline & 10,2 & 0,83 & $\begin{array}{r}5,59 \\
10\end{array}$ \\
\hline & $\begin{array}{l}20,0 \\
358\end{array}$ & $\begin{array}{l}0,24 \\
0,03\end{array}$ & 154 \\
\hline \multirow[t]{2}{*}{ Диметилсульфоксид } & 22,4 & 1,16 & 4,0 \\
\hline & 44,0 & 0,37 & 12,5 \\
\hline
\end{tabular}

* Условия реакции см. в табл. 1 . 
Рис. 1. Ингибирование термолизинового гидролиза 3-(2-фурил) акрилоил-глицил-Lлейцинамида под действием органических растворителей в пределах формального соблюдения уравнения (1). $\triangle-$ диоксан; $\times$ - диоксан, субстрат 3-(2-фурил) акрилоил-глицил-L-валинамид; $\nabla-\mathrm{N}, \mathrm{N}$. диметилформамид; - трет-бутанол; О - 1,4-бутандиол; $\square-$ диметилсульфоксид.

шаются. Влияние исследованных растворителей на кинетику гидролиза ФАГЛА примерно одинаково для термолизнна и протеиназы Bacillus brevis 7882 .

В случае диоксана уравнение обратимого ингибирования (1) соблюдается до достижения трех-

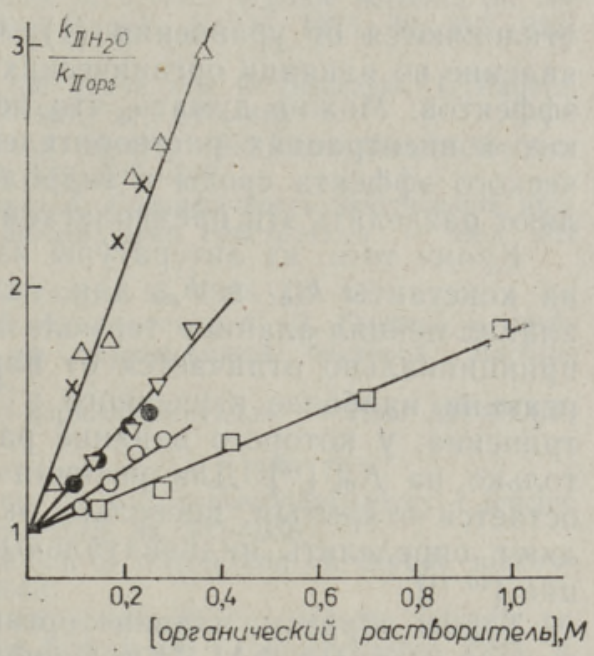
кратного ингибирования активности термолизина в реакции с ФАГЛА (рис. 1), что позволяет определить $K_{I}=0,18 \mathrm{M}$. На полученную прямую в координатах $k_{\mathrm{II} \mathrm{H}_{2} \mathrm{O}} / k_{\mathrm{II} \text { орг от }}$ [I] при этом ложатся и экспериментальные точки для другого субстрата ФАГВА, что также формально согласуется с механизмом обратимого ингибирования ферментативного гидролиза диоксаном. Для остальных

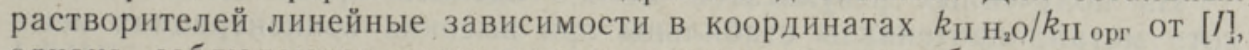
однако, соблюдаются менее чем до двукратного ингибирования активности фермента. Как видно из рис. 2, в достаточно широком интервале концентраций все зависимости, включая и кривую для диоксана,

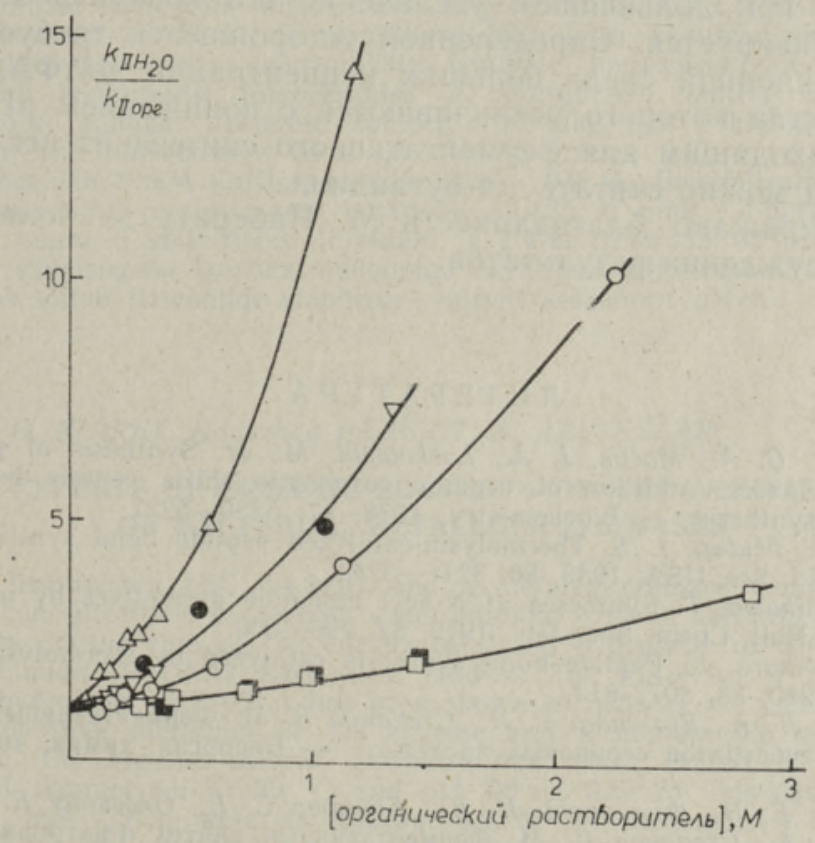

Рис. 2. Влияние органических растворителей на термолизиновый гидролиз 3-(2-фурил) акрилонл-глицин-L-лейцинамида (обозначе̂ния см. на рис, 1; 묘 - данные для диметилсульфоксида $\left.\left[{ }^{7}\right]\right)$.

$2^{*}$

227 
отклоняются от урав̈нния (1), что указывает на одновременное проявление во влиянии органических растворителей по меньшей мере двух эффектов. Можно думать, что несоблюдение уравнения (1) при высоких концентрациях растворителей связано с проявлением неспецифического эффекта среды в гидролизе, но полученные данные не позволяют разделить эти предполагаемые эффекты.

Кроме того, из литературы известно, что эффекты 10 об. \% ДМСО на константы $k_{c a t}$ и $K_{m}$ для гидролиза карбобензокси-n-нитрофенилаланил-лейцил-аланина термолизином соизмеримы по величине [17], что принципиально отличается от влияния органических растворителей на реакции наиболее изученного в этом отношении фермента - химотрипсина, у которого влияние растворителей практически сказывается только на $K_{m}\left[{ }^{18}\right]$. Для реакции термолизина с ФАГЛА этот вопрос остается открытым, поскольку экспериментальные трудности не позволяют определить индивидуальные константы $k_{\text {cat }}$ и $K_{m}$ в этой реакции $[10,11]$.

Таким образом, влияние органических растворителей на ферментативный гидролиз ФАГЛА в данном случае можно количественно охарактеризовать лишь через $I_{50}$, т. е. через концентрации растворителей, при которых наблюдается ингибирование активности фермента на $50 \%$. Найденные из рис. $2 I_{50}$ в случае термолизина имели следующие значения: $0,2 \mathrm{M}$ для диоксана, $1,4 \mathrm{M}$ для ДМСО, 0,35 М для трет-бутанола и ДМФА, 0,58 М для 1,4-бутандиола.

Из полученных результатов можно сделать практический вывод: хотя металлопротеиназы стабильны при высоких концентрациях некоторых органических растворителей - 1,4-бутандиола, диоксана, ДМФА (при высоких значениях рН), последние являются сравнительно сильными ингибиторами, что затрудняет их применение при ферментативном синтезе пептидов в присутствии этих протеиназ. Из числа изученных растворителей самым слабым ингибитором показал себя ДМСО, но его можно использовать лишь до $40 \%$-ных по объему концентраций, так как при дальнейшем увеличении его концентрации фермент быстро инактивируется. Определенной осторожности требует и применение в реакционной среде больших концентраций ДМФА, инактивирующие свойства которого увеличиваются с понижением рН раствора. Наиболее подходящим для ферментативного синтеза из исследованных растворителей можно считать 1,4-бутандиол.

Авторы выражают благодарность M. Пабериту за полезные замечания при обсуждении результатов.

\section{ЛИ Т Е Р А Т У Р А}

1. Homandberg, G. A., Mattis, J. A., Laskowski, M., Jr. Synthesis of peptide bonds by proteinases. Addition of organic cosolvents shifts peptide bond equilibria toward synthesis. - Biochemistry, 1978, 17, 5220-5227.

2. Wayne, S. I., Fruton, J. S. Thermolysin-catalyzed peptide bond synthesis. - Proc. Nat. Acad. Sci. USA, 1983, 80, 3241-3244.

3. Isowa, Y., Ichikawa, T. Syntheses of N-acyl dipeptide derivatives by metalloproteinases. - Bull. Chem. Soc. Jap., 1979, 52, 796-800.

4. Oka, T.. Morihara, K. Peptide bond synthesis catalyzed by thermolysin. - J. Biochem., $1980,88,807-813$.

5. Люблинская Л. А., Воюшина Т. Л., Степанов В. М. Ферментативный синтез пептидных субстратов сериновых протеиназ. - Биоорган. химия, 1982, 8, 1620 1624.

6. Лысогорская Е. Н., Филиппова Н. Ю., Бойщова С. Е., Оксенойт Е. С., Люблинская Л. А., Степанов В. М. Ферментативный синтез $n$-нитроанилидов пироглутамилпептидов - хромогенных субстратов пепсина. - Биоорган. химия, 1983, 9, 470-477.

7. Murphy, J., Rowlett, R., Smith, S. B. Hoeferlin, J. Kinetic studies of the binding of inhibitors to thermolysin. - Arch. Biochem. Biophys., 1980, 202, 405-413. 
8. Nakajima, H., Suzuki, K., Imahori, K. Effects of various organic solvents on the activity of thermolysin. - Nippon Nogei Kagaku Kaishi, 1975, 49, 317-323; Chem. Abstr. 1975, 83:159802y.

9. Schechter, I., Berger, A. On the size of the active site in proteases. I. Papain. - Biochem. Biophys. Res. Communs, 1967, 27, 157-162.

10. Pank, M., Kirret, O., Paberit, N., Aaviksaar, A. Hydrophobic interaction in thermolysin specificity. - FEBS Letters, 1982, 142, 297-300.

11. Панк M., Киррет O., Паберит Н., Аавиксаар А. Специфичность нейтральной протеазы Bacillus brevis в реакции с дипептидными субстратами. - Изв. АН ЭССР. Хим., 1983, 32, № 3, 157-162.

12. Яковлев В. А. Кинетика ферментативного катализа. М., 1965, 41-45.

13. Паберит Н. Ю., Панк М. С., Лийдерс М. А., Ванаталу К. П. Очистка и свойства нейтральной металлопротеазы из термофильной бактерии Bacillius brevis. - Биохимия, 1984, 49, 275-284.

14. Панк М., Киррет О. Синтез N-3-(2-фурил)-акрилонлпептидов. - Изв. АН ЭССР. Хим., 1979, 28, № 4, 297-300̈.

15. Стюарт Дж., Янг Дж. Твердофазный синтез пептидов. М., 1971, 76.

16. Khan, S. M., Darnall, D. W. The hydrolysis of 3-(2-furylacryloyl)-glycyl-L-leucine amide by thermolysin. - Anal. Biochem., 1978, 86, 332-336.

17. Morgan, G., Fruton, J. S. Kinetics of the action of thermolysin on peptide substrates. - Biochemistry, 1978, 17, 3562-3568.

18. Clement, G. E., Bender, M. L. The effect of aprotic dipolar organic solvents on the kinetics of $\alpha$-chymotrypsin-catalysed hydrolyses. - Biochemistry, 1963, 2, $836-843$.

Институт химии
Академии наук Эстонской ССР

Поступила в редакцию 31/V 1984

Ннститут химической и биологической физики Академии наук Эстонской ССР

Maret PANK, O. KIRRET, Nadežda PABERIT, A. AAVIKSAAR

\section{ORGAANILISTE LAHUSTITE MÕJU BAKTERIAALSETE METALLOPROTEINAASIDE AKTIIVSUSELE}

On uuritud termolüsiini (EC 3.4.24.4) ja Bacillus brevis 7882 metalloproteinaasi stabiilsust orgaaniliste solventide vesilahustes ning lahustite mõju 3-(2-furïül)akrüloüülglütsüül-leutsiinamiidi (FAGLA) fermentatiivse hüdrolüüsi kiirusele ning näidatud, et termolüsiini aktiivsuse langus orgaaniliste lahustite juuresolekul on vähemalt kahe efekti (fermendi konkurentse inhibeerimise ja hüdrolüüsile toimiva keskkonna mittespetsiifilise mōju) summa. Lahustite kontsentratsioonid, mis põhjustavad termolüsiini aktiivsuse $50 \%$-lise inhibeerimise $25^{\circ} \mathrm{C}$ ja $\mathrm{pH} 7,2$ juures $0,17 \mathrm{M}$ tris-maleaat- $\mathrm{NaOH}$ nuhvris, mis sisaldab $1 \mathrm{mM} \mathrm{CaCl}$, on: dioksaan $-0,2 \mathrm{M}$, dimetüülsulfoksiid $-1,4 \mathrm{M}$, N,N-dimetüülformamiid ja tertsiaarne butanool $-0,35 \mathrm{M}$ ning 1,4 -butaandiool -0.58 M. Fermendid osutusid stabiilseiks dioksaani ja 1,4-butaandiooli $80 \%$-listes (mahu $\%$ ) lahustes, kuid samasuguse kontsentratsiooniga N,N-dimetüülformamiidi ja dimetüülsulfoksiidi lahustes sõltub fermentide stabiilsus oluliselt keskkonna pH-st.

\section{Maret PANK, O. KIRRET, Nadezhda PABERIT, A. AAVIKSAAR}

\section{EFFECTS OF ORGANIC SOLVENTS ON THE ACTIVITY OF BACTERIAL METALLOPROTEINASES}

Stabilities of thermolysin (EC 3.4.24.4) and a metalloproteinase from Bacillus brevis 7882 at high concentrations of several water-miscible organic solvents, and the effects of the solvents, on the rate of the enzyme-catalyzed hydrolysis of 3-(2-furyl)acryloylglycyl-L-leucinamide (FAGLA) have been studied. The influence of the organic solvents on the hydrolysis of FAGLA has been shown to include as minimum two mechanisms - competitive inhibition of the enzyme and a non-specific medium effect in the hydrolysis. The organic solvent concentrations which caused $50 \%$ inhibition of the activity of thermolysin at $25{ }^{\circ} \mathrm{C}$ and $\mathrm{pH} 7.2$ in $0.17 \mathrm{M}$ Tris-acid maleate- $\mathrm{NaOH}$ buffer with $1 \mathrm{mM} \mathrm{CaCl} 2$ were as follows: $0.2 \mathrm{M}$ for dioxane, $1.4 \mathrm{M}$ for dimethyl sulfoxide, 0.35 for N,N-dimethyl formamide and tertiary butyl alcohol, and 0.58 for 1,4-butanediol. Both enzymes were equally stable in $80 \%(\mathrm{v} / \mathrm{v})$ dioxane and 1,4-butanediol while their stability in dimethyl sulfoxide and dimethyl formamide of the same concentration depended significantly upon $\mathrm{pH}$. 